\title{
ATENÇÃO E MOTIVAÇÃO: AVALIAÇÁO ATRAVÉS DE ESCALAS DE COMPORTAMENTO
}

\author{
Luciana SQUARIZI**
}

Professores e pesquisadores daUniversidade de Madrid, reuniram-se para escrever um livro de avaliação da motivação de estudantes, revisando e apontando caminhos atuais para conceitos como hiperatividade, desenvolvimento cognitivo, atenção e motivação.

O livro trata da avaliação da motivação no contexto escolar, analisando, sob enfoque neuropsicológico, os transtornos de atenção e sua relação com a capacidade intelectual e outros transtornos associados. Está dividido em duas partes, sendo a primeira teórica, composta por três capítulos.

O primeiro capítulo trata das habilidades acadêmicas e sua relação com a atenção e motivação, das baterias neuropsicológicas de avaliação, e da distinção entre os conceitos dificuldade de aprendizagem e problema de atenção. Motivação é considerado um construto de um processo psicológico que influencia a conduta, e que só pode ser inferida através de condutas específicas.

O segundo capítulo é específico e trata da questão da hiperatividade. Os autores baseiam-se no modelo neuropsicológico de Luria e nos conceitos sobre aprendizagem de Vygotsky, como a zona de desenvolvimento proximal.

Oterceiro capítulo tem um bom referencial a respeito de motivação e rendimento escolar. Neste capítulo faz-se uma distinção entre motivação intrínseca e motivação extrínseca e apresentam-se as principais argumentações para a relação entre as recompensas financeiras e sociais para o estudo. Aqui é lembrado como há tempos atrás a escolarização era um meiode ascendersocialmente, e portanto fonte de motivação intrínseca, e que hoje, na sociedade utilitária, não é mais. A sociedade atual está reforçando a motivação extrínseca, através de prêmios na TV etrabalhos não qualificados porém rentáveis.Ao mesmo tempo, professores mal formados e mal remunerados optam pela punição e pelo controle aversivo na sala de aula, contribuindo paraa redução da motivação intrínseca dos alunos.

Para avaliar a motivação, é proposta uma análise funcional, considerando a fase anterior à ação, a ação educativa e a fase posterior, observando o referido construto dentro do contexto em que o aluno está vivendo. Assim, os autores, em um exemplo de análise funcional, mostram que os alunos aprendem na sociedade atual que resposta nos estudos e reforçamento são independentes, tendo como consequência a crença na inutilidade da resposta.

Na segunda e última parte do livro encontram-se as escalas de avaliação de motivação e suas planilhas de correção, assim como as informações sobre sua construção. São dois tipos de escala: uma a ser preenchida pelos professores e outra a ser preenchida pelos pais.

O livro apresenta tabelas e algumas figuras, porém sempre de forma parcimoniosa e necessária, esclarecendo os critérios utiliza-

(*) Psicóloga, Mestranda em Psicologia Escolar pela PUC-Campinas 
dos, mas sem uma cansativa apresentação de fórmulas e tabelas. Merece atenção a abrangência da bibliografia, comtítulos que se estendem do ano de 1908 até 1997.

Os profissionais e estudantes de Psicologia encontrarão neste livro um ótimo referencial para a questão da atenção e da motivação em sala de aula, contando ainda com as escalas inéditas de avaliação.

(Manga, D; Garrido,I.; Pérez-Sólis María. (1997) Atencion y motivacion en aula. Importancia educativa y evaluación mediante escalas de comportamento infantil (ECI).Madrid, Europsique. 221p. 